\title{
Assessment of nutritional composition in elephant foot yam (Amorphophallus paeoniifolius Dennst- Nicolson) cultivars
}

\author{
Amit Singh $^{a^{*}}$, Arvind Chaurasiya $^{\mathrm{b}}$, And Surajit Mitra ${ }^{\mathrm{c}}$ \\ ${ }^{a}$ M S Swaminathan School of Agriculture, CUTM, Gajapati, Odisha -761211, India

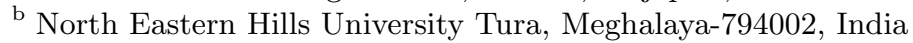 \\ c Bidhan Chandra Krishi Viswavidyalaya Mohanpur-741252, Nadia, WB, India \\ ${ }^{*}$ Corresponding author \\ amitsinghbckv@gmail.com
}

Received: 28 July 2015; Published online: 18 October 2016

\begin{abstract}
Elephant foot yams make a significant contribution to diets in tribal people of India. However, there is insufficient study of their nutritional and antioxidant value. In this paper the various traits of eleven cultivars of elephant foot yam: BCA-1, BCA-2, BCA-4, BCA-5, BCA-6, NDA-4, NDA-5, NDA-9, IGAM-1, AC-28 and Gajendra were studied and observed during the growth and development stage. The cultivar of BCA-6 contained the maximum amount of starch and total phenol at 100 Days After Planting (DAP) while cv., NDA-9 and NDA-5 showed the maximum content of starch and total phenol at 250 DAP respectively. However, the cultivar BCA-1 stored the maximum amount of carbohydrate at 100 DAP whereas ascorbic acid and $\beta$-carotene content was highest at 250 DAP. The protein amount was maximum in cv., BCA-2 and AC-28 at 100 and 250 DAP respectively. This information will provide breeders with the ability to develop desirable types of elephant foot yams having high yields and better nutritional profiles.
\end{abstract}

Keywords: Amorphophallus paeoniifolius; Cultivar; Composition; Antioxidant; Quality

\section{Introduction}

Elephant foot yam (Amorphophallus paeoniifolius Dennst-Nicolson) is locally used as a staple food in many Asian countries (Jansen, Wilk, \& Hetterscheid, 1996) and contributes both as tuber crops and vegetables to the diets of tribal people of India, particularly in rural areas where they are freely available. Among tropical aroid tuber crops, elephant foot yam has become popular due to high productivity in a short growing season and high net returns of 2103.7 to2629.6/ha. It contains vitamins, minerals, and energy (Bradbury \& Holloway, 1988; Chowdhury \& Hussain, 1979; Parkinson, 1984; Sakai, 1983) and has medicinal and therapeutic value (Chattopadhyay \& Nath, 2007). Elephant foot yam has some useful health benefits such as the root is carminative, restorative, stomachic and a tonic. It is dried and used in the treatment of piles and dysentery, where the fresh root acts as an acrid stimulant and expectorant. It is much used in our country in the treatment of acute rheumatism. It is basically a crop of South Eastern Asian origin and serves as a source of protein as well as starch. It has long been used as a local staple food in many countries such as the Philippines, Java, Indonesia, Sumatra, Malaysia, Bangladesh, India, China and South Eastern Asian countries (Chandra, 1984; Sugiyama \& Santosa, 2008). In India, it is cultivated in Andhra Pradesh, West Bengal, Gujarat, Kerala, Tamil Nadu, Maharashtra, Uttar Pradesh, and Jharkhand whereas in northern and eastern states, wild and local cultivars are 


\section{Nomenclature}

AC Amorphophallus Companulatus

BCA Bidhan Chandra Amorphophallus

C Cultivar

CD Critical difference

DAP Days after planting
IGAM Indira Gandhi Amorphophallus

NDA Narendra Dev Amorphophallus

S Ed Standard Error of Deviation

Y Year grown and generally used for making vegetable pickles and medicine preparations for various ailments (Ravi, Ravindran, \& Suja, 2009). It is an important member of the family Araceae and is gaining importance in tropical countries, not only as a food security crop but also as a cash crop due to its production potential and popularity as a starchy vegetable having high nutritive and medicinal values (O'Hair \& Asokan, 1986). Elephant foot yam along with other tropical arid tuber crops has now become an obvious candidate as a food security crop because of its capacity to do well on marginal soils even with low annual rainfall and its ability to give some return even in the years of droughts and flood (Mitra \& Tarafdar, 2008). Elephant foot yam also offers export potential since it is not commercially cultivated in other countries (Misra \& Shivlingaswamy, 1999; Misra, Shivlingaswamy, \& Maheshwari, 2001). The corms are usually eaten as a vegetable after boiling or baking and are rich in calcium $(50 \mathrm{mg} / \mathrm{g})$, phosphorus $(34 \mathrm{mg} / \mathrm{g})$ and vitamin A (260 IU/g). The leaves are used as a vegetable by local tribes in India because they contain high concentrations of vitamin A (Rajyalakshmi et al., 2001).

Elephant foot yam is considered to be a healthy low-fat food and is a rich source of essential fatty acids (Omega-3 fatty acids), which are known to increase the good anti cholesterol levels in the blood. Eating elephant foot yam consumption can increase the estrogen levels in women's bodies, thus helping to maintain the hormonal balance. It is also high in vitamin B-6, which provides relief from pre-menstrual syndrome in women. It is a natural product that is high in fiber. It can be used as slimming food because it lowers cholesterol levels and promotes weight loss and also has a high concentration of key minerals. People who are traditionally dependent on consumption of starch-rich foods may be unaware of the nutritive value of new high yielding varieties of elephant foot yam. Thus, along with the aim of increasing productivity of elephant foot yam, in this study, an attempt has also been made to reduce the acridity of the corms by selecting non-acrid cultivars, as well as nutritional importance and adopting suitable measures for making this crop more remunerative and popular. Consumers of elephant foot yam often select varieties having the best flavor, texture, and color rather than those having a better nutrient profile. Systemic morphological, horticultural and nutritional characterization for cultivars of elephant foot yam is lacking (Saikia \& Borah, 1994; Singh, Awasthi, \& Singh, 1999). The results of the qualitative evaluation of this crop by Chowdhury and Hussain (1979); Sakai (1983), Bradbury and Holloway (1988); and Santosa et al. (2002) were based mainly on the analyses of very few cultivars. For this study, elephant foot yam cultivars were evaluated for horticultural and nutritional parameters and antioxidant factors, to provide information to the breeders to develop desirable cultivars having a high yield and a better nutritional profile. 


\section{Materials and Methods}

\subsection{Collection of samples}

Eleven cultivars of elephant foot yam having smooth and glabrous pseudo-stems, collected from the State Agricultural Universities and Research Institutes under the Indian Council of Agricultural Research, India (Table 1), were evaluated at the research field of the All India Coordinated Research Project on Tuber Crops, Horticultural Research Station, Mondouri, Bidhan Chandra Krishi Viswavidyalaya, West Bengal, India, from 2010 to 2012. The soil was a slightly acidic ( $\mathrm{pH}$ 6.5) with sandy loam. The climate of the region is tropical humid with rainfall of 0.00 to $264.00 \mathrm{~mm}$, temperature maximum $37.59{ }^{\circ} \mathrm{C}$ and minimum $9.62{ }^{\circ} \mathrm{C}$ along with $\mathrm{RH}(\%) 96.87$ to 36.74 (Annual average) by AICRP on Agricultural Meteorology, BCKV, Kalyani, Nadia West Bengal.

\subsection{Physico-chemical analysis}

The physic-chemical traits of elephant foot yam were recorded from 10 randomly selected plants for each replication throughout the year at monthly intervals during growth and development by the following methods viz., starch by titration method (Moorthy \& Padmaja, 2002), ascorbic acid by (2, 6-dichlorophenol indophenols- Dye) titration method, $\beta$-carotene analyzed with the help of ELICO Bio-spectrophotometer at $452 \mathrm{~nm}$ (Ranganna, 1986) and carbohydrate at $630 \mathrm{~nm}$ (Thimmaiah, 2006), protein was estimated by Lowry's method (Lowry, Rosebrough, Farr, \& Randall, 1951) and total phenol was estimated by ELICO Bio-spectrophotometer (Swain \& Hillis, 1959; Walter, Purcell, \& Mccollum, 1979).

\section{$2.3 \quad$ Statistical procedure}

All the lab data arose from a Completely Randomized Design (CRD) as suggested by Raghuramula, Madhavan, and Sundaram (1983). The critical difference (CD) value at $5 \%$ level of probability was used for comparing the treatments and to find out the significant difference be- tween them. Each treatment was replicated three times. The data was analyzed using statistical software from AGRES version 3.01 (Data Entry Module for AgRes Statistical Software` 1994 Pascal Intl software solution).

\section{Results and Discussion}

From the statistical analysis of the results obtained, it could be concluded that the independent variable year (Y) affected starch, carbohydrate, ascorbic acid, protein, $\beta$-carotene and total phenol content of the crop. The interaction between year and cultivar (CY) affected both crop growth and development and Table 1 showed that all cultivars were collected from different places and smooth pseudostem type.

\subsection{Variation of starch, carbohydrate and protein content in elephant foot yam cultivars}

Physico-chemical composition of crop varied with cultivars and it was noticed that the starch and carbohydrate were found an in increasing trend during the growth and development stage. The lowest values of starch were found in cv., NDA4 and IGAM-1 at 100 and 250 DAP, respectively. While, the highest starch values were observed in cv., BCA-6 and NDA-9 at 100 and 250 DAP, respectively (Table 2). The range of starch content found in this experiment (4.21 $\%$ to $20.69 \%$ ) was compared to observations of Bradbury and Holloway (1988). The carbohydrate contents of elephant foot yam ranged from 16.7-75.13 mg/100g during different stages. The lowest carbohydrate content was found in cv., IGAM-1 at both 100 DAP (16.7 mg/100g) and 250 DAP (61.77 mg/100g) while, cv., BCA-1 was found highest $(47.46 \mathrm{mg} / 100 \mathrm{~g})$ at $100 \mathrm{DAP}$ and cv., BCA-5 (75.13 mg/100g) at 250 DAP (Table $3)$. These results were consistent with the results of a study by Gopalan, Rama-Sastri, and Bala Subramanian (1989) in elephant foot yam corm. The protein content was lowest in cv., NDA-9 at 100 DAP (3.79 \%) and BCA-6 at 250 DAP (1.17 $\%)$. The highest content of protein was for cv., 
Nutritional composition in elephant foot yam | 149

Table 1: Source and plant type of elephant foot yam cultivars

\begin{tabular}{llr}
\hline Cultivar & Source of cultivar in India & Pseudostem type \\
\hline BCA-1 & BCKV, Kalyani, West Bengal & Smooth \\
BCA-2 & BCKV, Kalyani, West Bengal & Smooth \\
BCA-4 & BCKV, Kalyani, West Bengal & Smooth \\
BCA-5 & BCKV, Kalyani, West Bengal & Smooth \\
BCA-6 & BCKV, Kalyani, West Bengal & Smooth \\
NDA-4 & NDUAT, Faizabad, Uttar Pradesh & Smooth \\
NDA-5 & NDUAT, Faizabad, Uttar Pradesh & Smooth \\
NDA-9 & NDUAT, Faizabad, Uttar Pradesh & Smooth \\
AC-28 & ANGRAU, Rajendranagar, Hyderabad & Smooth \\
IGAM-1 & IGKV, Raipur, Chhattisgarh & Smooth \\
Gajendra & ANGRAU, Rajendranagar, Hyderabad & Smooth \\
\hline
\end{tabular}

BCKV- Bidhan Chandra Krishi Viswavidyalaya; NDUAT- Narendra Dev University of Agriculture and Technology; ANGRAU- Acharya NG Ranga Rao Agricultural University; IGKV- Indira Gandhi Krishi Viswavidyalaya

BCA-2 at (5.44 \%) 100 DAP and AC-28 (1.86\%) at 250 DAP (Table 4). The decrease in protein content during growth and development might be due to the denaturation of protein caused by heat in the presence of moisture. Singh et al. (1999) also reported the variation in respect to moisture, protein, starch, carbohydrate, sugar and ascorbic acid within the cultivars of elephant foot yam during growth and development.

\subsection{Antioxidant compounds}

Antioxidant compounds in elephant foot yam varied with cultivar and year, and it was depicted that the ascorbic acid showed a decreasing trend during the growth and development phase while, $\beta$-carotene and total phenol showed an increasing trend. The ascorbic acid content was lowest in cv., IGAM-1 at 100 DAP and NDA5 at 250 DAP. The highest amount of ascorbic acid was noticed in cv., BCA-5 at 100 DAP (10.95 mg/100g) and BCA-1 at 250 DAP (3.09 $\mathrm{mg} / 100 \mathrm{~g}$ ) (Table 5 ). The higher ascorbic acid content at the initial stage of harvest might be attributed to an adequate supply of hexose sugar via photosynthetic activity and the reduction in ascorbic acid at the later stages might be related to an enzymatic loss of ascorbic acid through oxidation as indicated by Mapson (1970). The $\beta$-carotene content was lowest in cv., Gajendra $(83.43 \mu \mathrm{g} / 100 \mathrm{~g})$ at $100 \mathrm{DAP}$ and BCA-6 (210.82 $\mu \mathrm{g} / 100 \mathrm{~g})$ at $250 \mathrm{DAP}$. The highest amount of $\beta$ carotene was in cv., IGAM-1 $(169.03 \mu \mathrm{g} / 100 \mathrm{~g})$ at $100 \mathrm{DAP}$ and BAC-1 $(338.13 \mu \mathrm{g} / 100 \mathrm{~g})$ at 250 DAP (Table 6$)$. The range of $\beta$-carotene content found in this experiment (83.43 to 338.13 $\mu \mathrm{g} / 100 \mathrm{~g})$ was in line with the results observed by Onwueme (1978). The reports on the total phenol composition of elephant foot yam are limited. However, total phenol content was lowest in cv., NDA-4 (42.87 mg/100g) at 100 DAP and BCA-1 (45.79 mg/100g) at 250 DAP. The highest amount of total phenol was for cv., BCA-6 (46.74 mg/100g) at 100 DAP and NDA-5 (54.55 $\mathrm{mg} / 100 \mathrm{~g}$ ) at $250 \mathrm{DAP}$ (Table 7).

\section{Conclusions}

The analyzed elephant foot yam corms contained more starch, carbohydrate, ascorbic acid, protein, $\beta$-carotene and total phenol. These and other cultivars can be used to improve yield of this crop in West Bengal, Uttar Pradesh, Hyderabad and Chhattisgarh and other environments. It can be concluded that cultivars such as BCA1, IGAM-1, BCA-5 and AC-28, having good nutritional value, antioxidant properties and suitability to be transformed into processed products like dried cubes, fried cubes and pickle, can be selected for further improvement and can be promoted for cultivation. These results suggest that this less familiar vegetable should not be

\begin{tabular}{l|l|l|l} 
IJFS & October 2016 | Volume 5 & pages 146-157
\end{tabular} 
$150 \mid$ Singh et al.

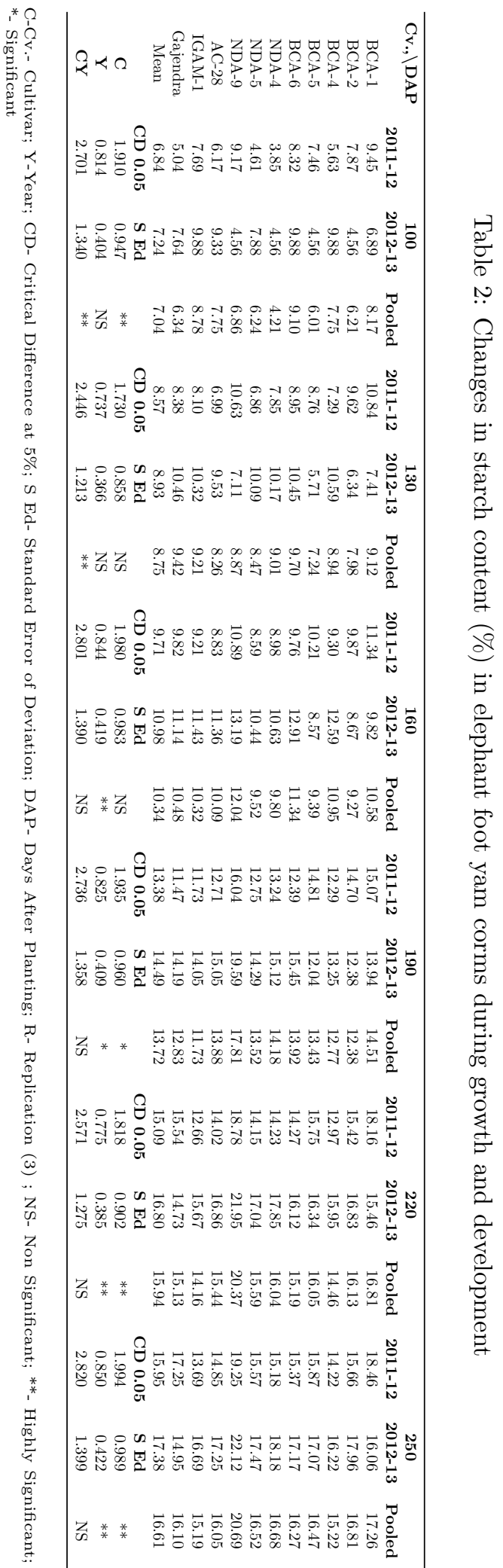

IJFS | October 2016 | Volume 5 | pages 146-157 
Nutritional composition in elephant foot yam |151

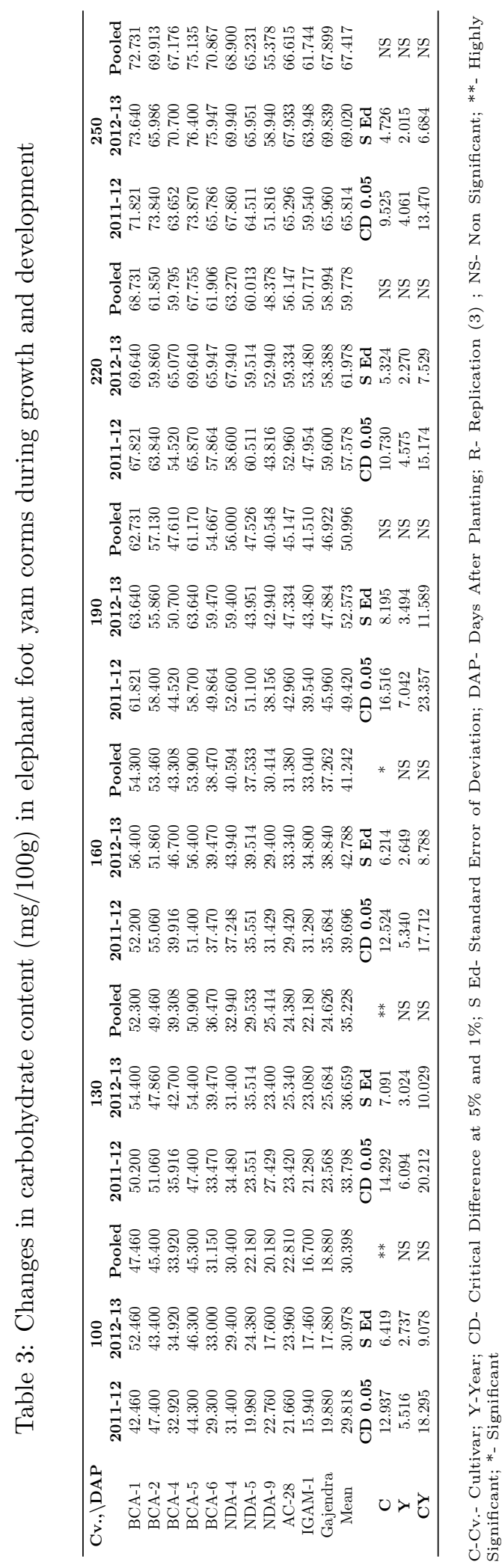

IJFS | October 2016 | Volume 5 | pages 146-157 
152 Singh et al.

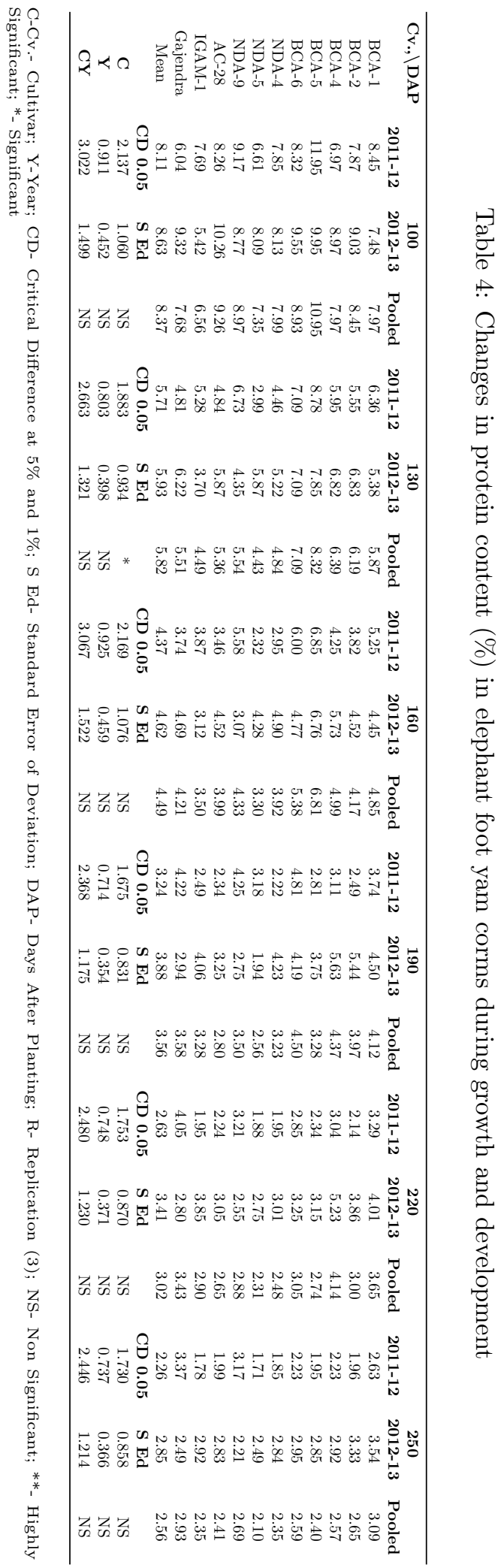

IJFS | October 2016 | Volume 5 | pages 146-157 
Nutritional composition in elephant foot yam $\mid 153$

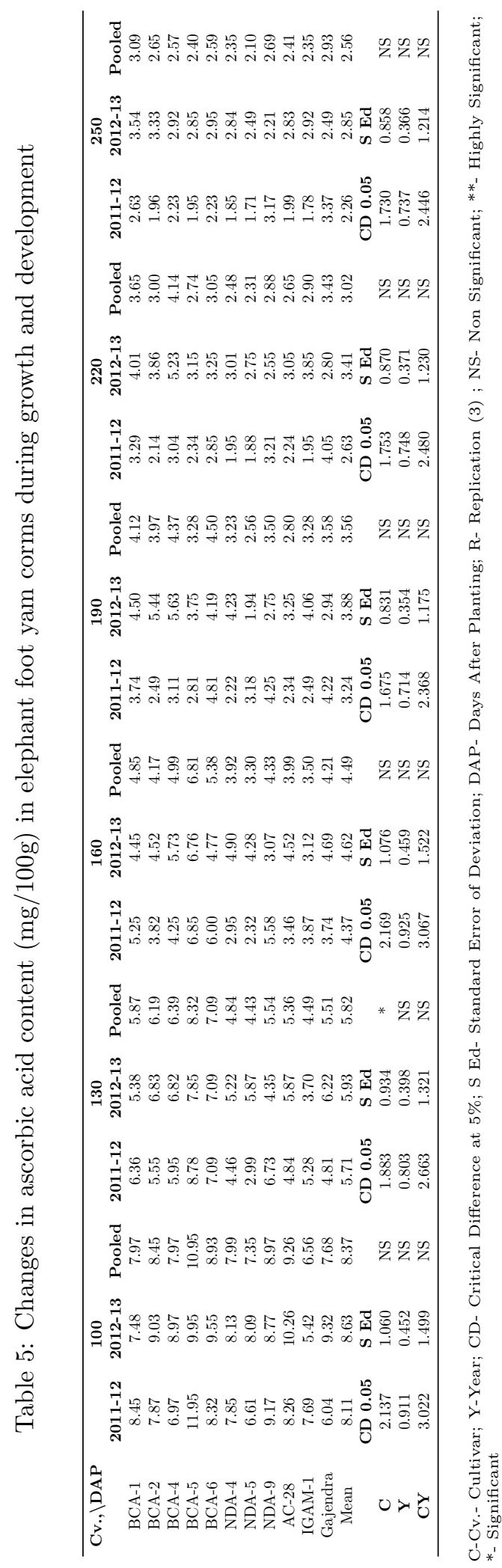

IJFS | October 2016 | Volume 5 | pages 146-157 
$154 \mid$ Singh et al.

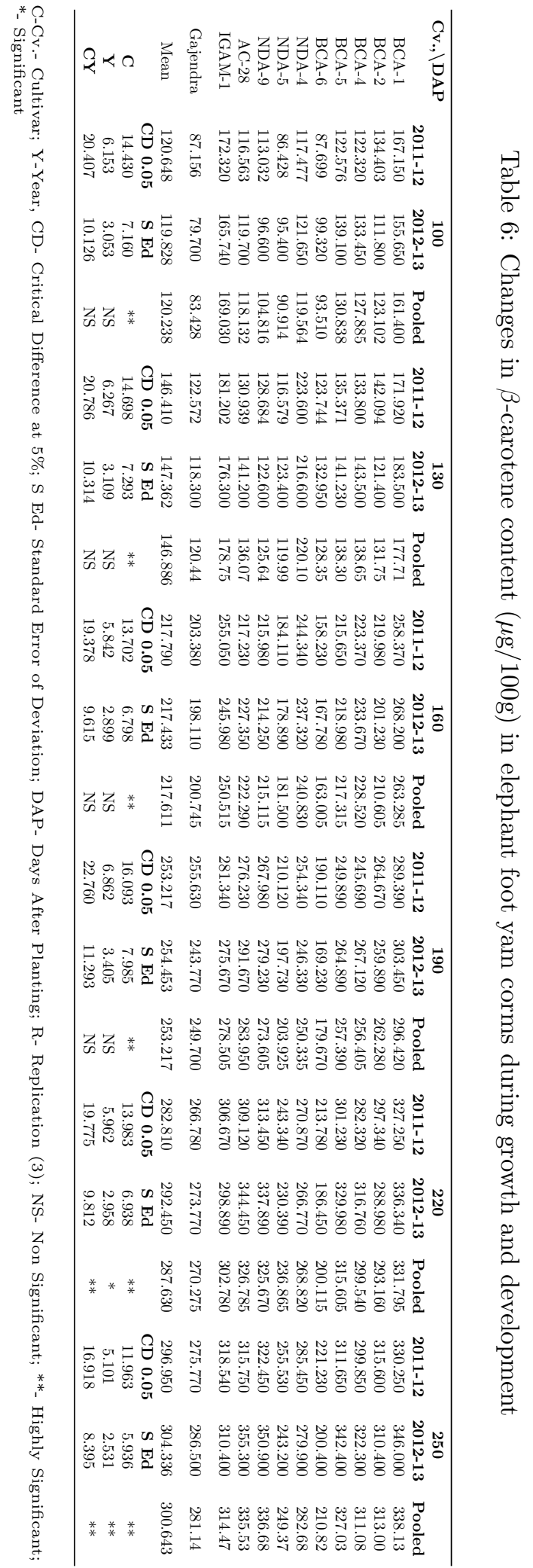

IJFS | October 2016 | Volume 5 | pages 146-157 
Nutritional composition in elephant foot yam $\mid 155$

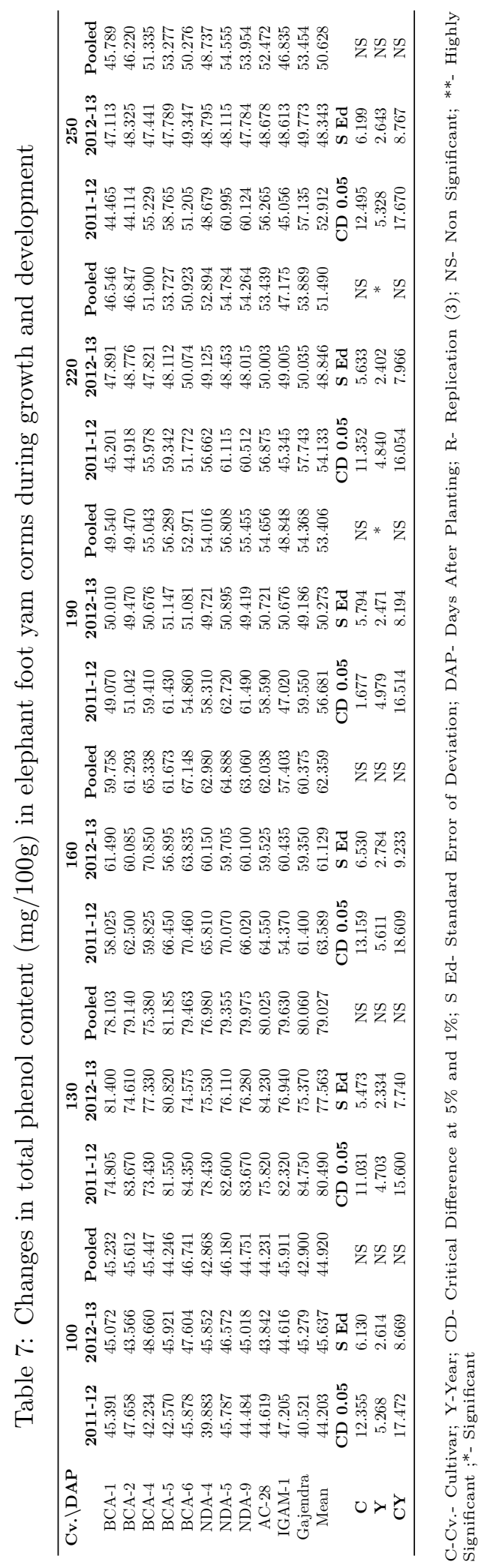

IJFS | October 2016 | Volume 5 | pages 146-157 
ignored. Rather they can be used as a good alternative source of food to alleviate hunger and malnutrition, which are currently big problems in developing countries such as India. We hope that this study will help propagate knowledge on the compositional varietal variation in elephant foot yam corms, their suitability for transformation into processed products like dried cubes, fried cubes and pickle, and their selection for further improvement. Furthemore, we hope this study willstimulate activity to promote the production and utilization of elephant foot yam as valuable components of a well balanced diet.

\section{Acknowledgements}

The authors are thankful to AICRP on Tuber Crops, BCKV, West Bengal, India for providing analytical facilities and also wish to thank Prof. Surajit Mitra for his support during the research work and Dr. A. K. Chaurasiya for statistical analysis.

\section{References}

Bradbury, J. H. \& Holloway, W. D. (1988). Chemistry of tropical root crops: significance for nutrition and agriculture in the Pacific. Australian Centre for International Agricultural Research, Canberra, Australia. Retrieved from http://aciar.gov.au/files/ node/2267/mn6_pdf_18359.pdf

Chandra, S. (1984). Edible aroids. Oxford University Press, USA.

Chattopadhyay, A. \& Nath, R. (2007). Medicinal importance of some well known and unexploited roots and tubers. Agriculture update. Hind. Agri-Hort. Soc, 2, 80-82.

Chowdhury, B. \& Hussain, M. (1979). Chemical composition of the edible parts of aroids grown in Bangladesh. Indian Journal of Agricultural Sciences, 49(2), 110-115.

Gopalan, G., Rama-Sastri, B., \& Bala Subramanian, S. (1989). Nutritive value of indian foods. National Institute of Nutrition. ICMR, Hyderabad.
Jansen, P. C. M., Wilk, C., \& Hetterscheid, W. L. A. (1996). Amorphophallus blume ex decaisne. In M. Flach \& F. Rumawas (Eds.), (Chap. PROSEA 9: Plant Yielding Non-seed Carbohydrates. Leiden: Backhuys Publ. pp. 45-50).

Lowry, O. H., Rosebrough, N. J., Farr, A. L., \& Randall, R. J. (1951). The original method. The Journal of Biological Chemistry, 193, 265.

Mapson, L. W. (1970). Biochemistry of fruits and their products. In A. C. Hulme (Ed.), (Chap. Vitamins in fruits, Vol. 1, pp. 369384). Academic Press: London.

Misra, R. S. \& Shivlingaswamy, T. M. (1999). Elephant foot yam: a tropical tuber crop with high yield potential. In 7th agricultural science congress, february (pp. 2124).

Misra, R. S., Shivlingaswamy, T. M., \& Maheshwari, S. K. (2001). Improved production technology for commercial and seed crops of elephant foot yam. Journal of Root Crops, 27(1), 197-201.

Mitra, S. \& Tarafdar, J. (2008). Present status and future prospects of elephant foot yam cultivation in west bengal. in palaniswami, m. s. et al. ed., national seminar on amorphophallus: innovative technologies, july 19-20, 2008, patna, bihar-abstract book, status papers and extended summery, 2529.

Moorthy, S. N. \& Padmaja, G. (2002). A rapid titrimetric method for the determination of starch content of cassava tubers. Journal of Root Crops, 28(1), 30-37.

O'Hair, S. K. \& Asokan, M. P. (1986). Edible aroids: botany and horticulture. In Horticultural reviews (pp. 43-99). John Wiley \& Sons, Inc. doi:10.1002/9781118060810.ch2

Onwueme, I. C. (1978). The tropical tuber crops: yams, cassava, sweet potato, and cocoyams. New York: John Willey and Son's, 168-171.

Parkinson, S. (1984). Contribution of aroids in the nutrition of people in the South Pacific. In S. Chandra (Ed.), (pp. 215-224). Edible aroids. Oxford: Clarendon Press.

Raghuramula, H., Madhavan, N. K., \& Sundaram, K. (1983). A manual of laboratory technology. National Institute of Nutri- 
Nutritional composition in elephant foot yam $\mid 157$

tion, Indian Council of Medical Research, Jamia-Osmania. Hyderabad 500007 AP. India.

Rajyalakshmi, P., Venkatalaxmi, K., Venkatalakshmamma, K., Jyothsna, Y., Devi, K. B., \& Suneetha, V. (2001). Total carotenoid and beta-carotene contents of forest green leafy vegetables consumed by tribals of south India. Plant Foods for Human Nutrition, 56(3), 225-238. doi:10.1023/A : 1011125232097

Ranganna, S. (1986). Handbook of analysis and quality control for fruit and vegetable products. Tata McGraw-Hill Education.

Ravi, V., Ravindran, C. S., \& Suja, G. (2009). Growth and productivity of elephant foot yam (Amorphophallus paeoniifolius (Dennst.) Nicolson): an overview. Journal of Root Crops, 35(2), 131-142.

Saikia, T. \& Borah, R. C. (1994). Biochemical composition of acrid and non-acrid amorphophallus corms. Journal Agric. Sci. Soc. Northeast India, 7, 90-91.

Sakai, W. S. (1983). Aroid root crops: alocasia, cyrtosperma and amorphophallus. handbook of tropical foods (chan, hc (jr.), ed.) In H. Chan (Ed.), (pp. 29-83). Handbook of tropical foods. New York: Marcel Dekker.

Santosa, E., Sugiyama, N., Muhamad, C., Lontoh, A., Sudiatso, S., Kawabata, S., ... Hidayat, S. (2002). Morphological and nutritional characterization of elephant foot yam in indonesia. Journal of Tropical Agriculture, 46(4), 265-271.

Singh, A. B., Awasthi, C. P., \& Singh, N. (1999). Biochemical composition and nutritive value of promising collections of different elelphant foot yam (amorphophallus companulatus (roxb.) Vegetable Science, 26(2), 186-187.

Sugiyama, N. \& Santosa, N. (2008). Edible amorphophallus in indonesia - potential crops in agroforestry. Bulaksumur, Yogyakarta: Gadjah Mada University Press P.O. Box. 14.

Swain, T. \& Hillis, W. E. (1959). The phenolic constituents of Prunus domestica. I.-The quantitative analysis of phenolic constituents. Journal of the Science of Food and Agriculture, 10(1), 63-68. doi:10.1002/ jsfa. 2740100110

Thimmaiah, S. K. (2006). Standard methods of biochemical analysis. Kalyani publishers.

Walter, W. M., Purcell, A. E., \& Mccollum, G. K. (1979). Use of high-pressure liquidchromatography for analysis of sweetpotato phenolics. Journal of Agricultural and Food Chemistry, 27(5), 938-941. doi:10.1021/jf60225a031 